Юлия Егорова

ORCID: 0000-0001-6037-0466

Институт мировой литературы им. А.М. Горького

Российской академии наук

Москва, Россия

\title{
МЕЖДУ ИСПОВЕДЬЮ И ПРОПОВЕДЬЮ: ПОВЕСТЬ М. ГОРЬКОГО ИСПОВЕДЬ
}

https://doi.org/10.34739/clit.2020.14.11

\section{BETWEEN CONFESSION AND SERMON: THE STORY OF M. GORKY CONFESSION}

\begin{abstract}
The story Confession occupies a special place in M. Gorky's creation. It was conceived and written during a period in which he of searched for God. According to the writer's plan, the work tells us of a person who walks in holy places, lives in monasteries and searches for God. In reference to the plot of Confession, it is worth noting that it was based on real sources, including the life of Gorky himself. In a way, the narrative was the result of the philosophical and artistic inquiries of the writer at the turn of the century.

Keywords: Gorky, Confession, searching for God
\end{abstract}

Особое место в творчестве М. Горького занимают повести Мать (вторая половина 1906 - начало 1907 г.) и Исповедь (конец декабря 1907 - начало марта 1908 г.). Первое было создано в период активного увлечения богостроительством, второе - в период богоискательства. Приступая к Исповеди, Горький предполагал написать небольшой рассказ «листов на пять», однако работа настолько увлекла писателя, что довольно скоро его объем дошёл до десяти листов. В письме К.П. Пятницкому от 27 января 1908 г. писатель говорил уже о повести: «Очень захвачен повестью, пишу

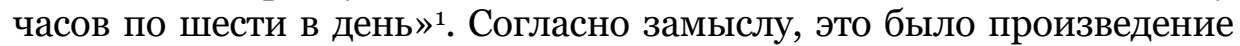
под рабочим названием Житие, рассказывающее о хождении человека по святым местам, о жизни в обителях и о поисках Бога. Повесть предваряло посвящение Ф.И. Шаляпину.

${ }^{1}$ М. Горький, Полное собрание сочинений. Писъма. В 25 тт., Т. 6, Москва 2000, с. 170. 
Говоря о сюжете Исповеди стоит отметить, что она написана на реальных материалах: рассказе нижегородского сектанта и рукописи ссыльного попа Левонтия Поморца. С ней Горький познакомился еще в начале своего творческого пути. Сделав из рукописи выписки, он решил написать повесть, однако работа не заладилась, и писатель сжег её. В дальнейшем отдельные сцены найдут отражение в Исповеди. Также в ней Горький описал ряд юношеских воспоминаний, связанных с его хожениями по святым местам, монастырям и обителям центральной части и юга России, беседы со схимниками и монахами.

Решение отправиться в странствие Горький принял после ряда трагических событий, произошедших в его жизни, и, как следствие, предпринятой в декабре 1887 г. попытки самоубийства. За дерзкий поступок молодого человека на семь лет отлучили от церкви. Чувства, пережитые в те годы, Горький описал следующим образом: «Душа моя сильно болела. И если б, два года тому назад, я не убедился личным опытом, как унизительна глупость самоубийства, наверное, применил бы этот способ лечения больной души» ${ }^{2}$. Опустошенность, смешанная со жгучим чувством стыда за содеянное, острая необходимость в обретении новой веры и нового бога подтолкнули молодого человека на поиски точки опоры. Летом 1890-го года он отправился по монастырям в поисках духовной пищи у монахов и пророков. В одном из них ему удалось встретиться с Иоанном Кронштадским, знакомство с которым сыграло важную роль в дальнейшей судьбе молодого писателя. Итоги драматических событий тех лет, паломничество по святым местам, беседы с монахами привели к тому, что

(...) лет в 20, под влиянием впечатлений, воспринятых от природы, от «космоса», (...) от стихийных сил, вне меня бытийствующих, - я поставил перед собой вопрос о Боге уже не как творце людей, а как создателе вселенной и владыке сил, враждебных мне, человеку: зноя, холода, ветра, как о хозяине, распределившем блага земли мучительно неравномерно: здесь - плодородный чернозем, а для других бесплодный камень, солончаки, известковые породы, песок. (...) Об этом я беседовал с учеными монахами-магистрантами, схимниками, богословами сектантскими начетчиками, и эти люди окончательно, навсегда сделали меня атеистом ${ }^{3}$.

Еще одним подтверждением того, что хожения Горького нашли отражение в повести Исповедь, стало наблюдение

2 М. Горький, op. cit., c. 207.

3 Архив Горького, ПГ-рл-19-25-1. 
Г.В. Антюхина, высказанное в книге Очерки истории печати Воронежского края, 1798-1917: «Впечатление от жизни на воронежской земле отразилось в повести М. Горького Исповедъ»4.

Поиски собственной правды, смысла жизни и места Бога в мире многократно усилили интерес Горького к книгам. В период 1890-х-1900-х Алексей Пешков познакомился с трудами по истории философии и книгами зарубежных мыслителей: Д. Селли, Э.-М. Каро, В. Штейна и др. Начинающего писателя увлекло изучение природы и ее законов, проблем социума, общественной жизни и человека. Горький пытался найти причины страданий человечества и пути избавления от них, новую веру и собственную эстетику. В этом ему помогли книги Т.Г. Гексли Введение в изучение зоологии и Введение в науку, И.-В. Гёте Фауст, О правде и правдоподобии произведений искусства; Б. Спинозы, Дж. Рескина и др. На рубеже XIX-XX веков он почувствовал острую необходимость в экстренных переменах внутри себя, собственных взглядов и ориентиров. В течение нескольких лет Горький пересмотрел свою литературную и жизненную позиции. Благодаря знакомству с трудами классиков философии, естествознания, эстетики и литературы Горький стал остро ощущать массовое измельчание литературы, идеологии и культуры. Ему хотелось, чтобы литература стремилась «трактовать вопросы коренные, вопросы духа», была проникнута реализмом, возвышающимся «до одухотворенного и глубоко продуманного символа», поднимала человека «от реальностей до философских обобщений»5. Наступившее столетие Горький провозгласил веком личности и активной деятельности во благо всех людей земли:

Личность, человек - вот она драгоценнейшая наша реальность. Личность чувствует себя совершенно правильным выводом из посылок прошлого и необходимейшей посылкой в будущее. Личность ощущает себя в центре жизни, в средине ее потока, она мужественно сознается в ограниченности своих личных сил, она мыслит чувствует исторически, знает, что ее бытие обусловлено именно в тех формах, в той среде, в коих она существует и которые она призвана расширить, изменить, сделать более удобной для живых людей, идущих вслед за нею, личностью, творящей новые формы жизни. Она - всегда активна, ибо насыщена живой силой прошлого ${ }^{6}$.

\footnotetext{
4 Антюхин Г.В., Очерки истории печати Воронежского края 1798-1917, Воронеж 1973, c. 149.

5 Горький М., op. cit., с. 294-295.

${ }^{6}$ Ibidem, c. 60.
} 
Обретенные ценности и ориентиры Горький отразил в повести Исповедь. В письме Е.П. Пешковой от начала марта 1908 г. он раскрыл главную идею своего нового произведения:

В новой моей повести я старался осветить путь к слиянию с целым счастье и источник высших наслаждений духа именно в этом слиянии, - нигде кроме.

Всякая личность - если это духовно здоровая величина - должна стремиться к миру, а не от мира - вот теза повести. Имею смелость думать, что она мною доказана. (...) А всё личное, - как я убедился, удивительно ничтожно. Отнюдь не рекомендуя отказываться от себя, я говорю только о необходимости найти, понять и растить в себе человеческое. Личное - мало человечно7.

Сразу после выхода повести в свет Горького пытались обвинить в богохульстве. Московский протоиерей Восторгов отправил председателю Совета министров П.А. Столыпину телеграмму следующего содержания:

Русское монархическое собрание почтительно просит Ваше высокопревосходительство изъять из обращения Исповедь Горького, 23 выпуск «Знания», как ниспровергающую религию и проповедующую вражду к правительству и социал-демократию в выражениях 1905 года $(. . .)^{8}$.

Повесть вызвала большой интерес, отклики о ней были довольно разнообразными, порой даже противоположными. Мнение о новом произведении высказывалось не только в газетах, журналах, литературных альманах и сборниках. Горького интересовали отклики об Исповеди своих друзей и близких, видных общественных и политических деятелей. В письме от 15 января 1909 года из Петербурга А.Н. Тихонов сообщал: «Ваша Исповедь не даёт здесь никому покою. Много о ней говорят и „за заставой”, иные считают её за „Евангелие пролетариата”, другие, (...) толкуют о „мистицизме”. (...) Большая и поучительная разноголосица»9. Различные слои общества интересовали поднятые в Исповеди проблемы, вопросы о влияниях, испытанных автором и нашедших освещение на её страницах. Высокую оценку повести дал Амфитеатров в письме от 25 мая 1908 года: «У нас в доме повальный благоговейный восторг пред Исповедью. Я уже в третий раз читаю, и мне всё больше и больше она нравится. Вечной красоты и правды полна эта вещь

7 Ibidem, c. 196.

${ }^{8}$ Архив Горького, ЦД-5-23.

9 Архив Горького, КГ-п-75-9-1. 
удивительная. И уж до чего она - русская!»10. В августе 1909 года он снова выразил своё восторженное мнение:

Я, знаете, твердо уверен, что в Исповеди стали Вы на путь к литературному евангелию и дадите нам его всенепременно и самостоятельно. И это самое важное и хорошее, чего ждёт от Вас русское общество, и никакая другая Ваша деятельность, в которую Вы себя втиснете, не возместит даже тысячной доли этого огромного и справедливого ожидания ${ }^{11}$.

Наряду с положительными откликами Горький получал негативные и довольно сдержанные отзывы:

Недавно перечитал Вашу Исповедъ. В конце Исповеди (думается мне, бессознательно как бы для подтверждения истинности Вашей религии, могущества Вашего бога), Вы не отказали этому богу в удовольствии поразить верующих чудом: народ-бог исцеляет безногую девушку, - писал С.С. Кондурушкин в письме от 28 ноября 1909 г. - И хоть «чудо» - то это у Вас не чудо, но тем не менее оно по форме так похоже на чудеса Христовы, и Магометовы, и Буддины и проч. и проч. (...) Это - простите, дорогой Алексей Максимович, слишком «программно», рассудочно ${ }^{12}$.

В русской печати высказывалось мнение, что Горький в художественной форме, посредством образов и речей героев пересказал идеи Луначарского, навещавшего писателя на Капри. Однако А.А. Золотарёв считал, что идейной вдохновительницей, под влиянием которой была написана Исповедь, стала Италия, а точнее римские впечатления Горького.

Повесть Исповедь принадлежала к числу тех произведений писателя, которые получили огромное количество рецензий, откликов и статей. Даже те, кто после выхода повести Мать говорили о художественном конце Горького (в том числе и Д.В. Философов), отметили возрождение его таланта и новый виток в творчестве художника. Критик либерального толка А.А. Измайлов в своей статье Русский человек на духу находил повесть своевременной, считал, что «настроение „богоискания” могло особенно обостриться после того, как политический бурун пробежал по всему огромному морю русской действительности, всколыхнул его мертвую зыбь и переставил все точки и линии по-новому» ${ }^{3}$. По его мнению, Горький «имеет дело

\footnotetext{
${ }^{10}$ Архив Горького, КГ-п-2-1-6.

${ }^{11}$ Ibidem, КГ-п-2-1-31.

${ }^{12}$ Ibidem, КГ-п-37-2-11.

13 А.А. Измайлов, Русский человек на духу, „Образование” 1908, № 7, отд. III, с. 4.
} 
с душой русского простеца». Изображенный им герой - «неудачник из подкидышей, ищет бога и веры», его «живая душа» не приемлет религии «трусов и рабов, деспотов и маньяков». Его проповедь, по мнению Измайлова, является проповедью самого Горького, который «под многим подписался бы в этой исповеди». Это «не есть проповедь холодной и умной религии социализма. Здесь экстаз, зной, волнение, трепет, каких не знает та религия» ${ }^{14}$.

В современном российском горьковедении продолжаются споры и дискуссии вокруг Исповеди, что лишний раз доказывает актуальность данного произведения. В 1999 году была защищена кандидатская диссертация по теме «Повесть Исповедь в системе художественных и философских исканий М. Горького» 15 . Её автор, Е. Никитин высказывает мнение, что философией повести является пропаганда коллективизма, призыв к «собиранию человека», говоря языком А.А. Богданова. На его идеи в своём творчестве опирался не только М. Горький, но и богостроители А.В. Луначарский и В.А. Базаров.

Исследователь творчества А.М. Горького Л.А. Спиридонова отмечает, что странник - постоянный герой в произведениях писателя 1910-х годов. Наряду с Матвеем из повести Исповедь, находится в поисках истинной веры и смысла жизни.

Вслед за А.А. Богдановым и А.В. Луначарским, - отмечает Л. Спиридонова, - Горький пытается соединить религию c социализмом. Он проповедует идею «собирания» человека в единое неодолимое целое. «Бог-народушко», объединенный общей верой, по мысли писателя, способен творить чудеса. (...) Торжествует мысль о народе как единственной созидающей силе, которая способна преобразить землю и людей. (...) Таким образом, народ уравнивается с создателем мира, а мифотворчество Горького приобретает облик богостроительства ${ }^{16}$.

Повести М. Горького Мать и Исповедь стали своего рода итогом философских и художественных исканий писателя на рубеже веков, периода богостроительства и сменившего его богоискательства. И если в первой повести Горький ставит на место бога Человека, то во второй - народ, объединенный общей верой. Сюжетная ткань Исповеди представляет собой переход от богопочетания к народопочетанию. Свои новые убеждения Горький

14 Ibidem, c. 6.

15 Н.Е. Никитин, Повесть «Исповедь» в системе художественньх и философских исканий М. Горького, Диссертация на соискание ученой степени кандидата филологических наук, Москва 1999.

16 Л. Спиридонова, М. Горъкий: новый взгляд, Москва 2004, с. 186. 
вложил в уста главного героя Матвея. Сначала мысль о том, что народ способен занять место бога, кажется Матвею в чем-то крамольной, но к концу повествования он уверовал в эту возможность. Его исповедь становится своего рода проповедью новых взглядов самого автора.

\section{Литература}

Антюхин Г.В., Очерки истории печати Воронежского края 1798-1917, Воронеж 1973.

Архив Горького, КГ-п-2-1-6.

Архив Горького, ПГ-рл-19-25-1.

Архив Горького, ЦД-5-23.

Архив Горького, КГ-п-2-1-31.

Архив Горького, КГ-п-37-2-11.

Архив Горького, КГ-п-75-9-1.

Горький М., Полное собрание сочинений. Письма. В 25 тт., Т. 6, Москва 2000.

Измайлов А.А., Русский человек на духу, „Образование” 1908, № 7, Отд. III, с. 1-11.

Никитин Н.Е., Повесть «Исповедь» в системе художественных и философских исканий М. Горького, Диссертация на соискание ученой степени кандидата филологических наук, Москва 1999.

Спиридонова Л., М. Горький: новый взгляд, Москва 2004.

\section{References}

Antûhin G.V., Očerki istorii pečati Voronežskogo kraâ 1798-1917, Voronež 1973.

Arhiv Gor'kogo, KG-p-2-1-6.

Arhiv Gor'kogo, PG-rl-19-25-1.

Arhiv Gor'kogo, CD-5-23.

Arhiv Gor'kogo, KG-p-2-1-31.

Arhiv Gor'kogo, KG-p-37-2-11.

Arhiv Gor'kogo, KG-p-75-9-1.

Gor'kij M., Polnoe sobranie sočinenij. Pis'ma. V 25 tt., T. 6, Moskva 2000.

Izmajlov A.A., Russkij čelovek na duhu, „Obrazovanie” 1908, № 7, otd. III, S. 1-11.

Nikitin N.E., Povest' «Ispoved'» $v$ sisteme hudožestvennyh i filosofskih iskanij M. Gor'kogo, Dissertaciâ na soiskanie učenoj stepeni kandidata filologičeskih nauk, Moskva 1999.

Spiridonova L., M. Gor'kij: novyj vzglâd, Moskva 2004. 